\title{
Strategy and Economic and Legal Principles of the Land Market Formation
}

\author{
Submitted 21/04/20, $1^{\text {st }}$ revision 25/05/20, $2^{\text {nd }}$ revision 30/06/20, accepted 15/08/20 \\ Olena S. Litoshenko ${ }^{1}$, Pavlo F. Kulynych ${ }^{2}$, Tetyana V. Kurylo ${ }^{3}$, \\ Iryna M. Tsvigun ${ }^{4}$, Oleh I. Kachanovskyi ${ }^{5}$, Andrii O. Dligach ${ }^{6}$
}

\begin{abstract}
:
Purpose: The main purpose of this study is to determine the strategy, economic and legal framework in the formation of the land market.

Design/Methodology/Approach: The study is based on the definition of the main aspects of state management of the land market in the leading countries of the world, as well as on the main legal documents that are governing the formation and effective functioning of the land market.

Findings: The results of the study show that agricultural land is a valuable resource not only in EU member states, but also in Ukraine. In the leading countries of the world public authorities have the opportunity to regulate the maximum amount of available agricultural ownership per family with the help of the created appropriate mechanism. In addition, the main advantages are described. These advantages can be achieved with the introduction and effective functioning of the land market.

Practical Implications: The study helps to raise awareness in the field of land relations, particularly during the introduction and effective functioning of the land market.

Originality/Value: The study emphasizes that the importance of strategy development and compliance with economic and legal principles in the formation of the land market will create benefits for the country's economy.
\end{abstract}

Keywords: Land market, land relations, property right (ownership) to land, legal regulation.

JEL Codes: Q1, Q18, R5, R52. Paper Type: Research article.

\footnotetext{
${ }^{1}$ Associate Professor, Kyiv National Economic University named after Vadym Hetman, Kyiv, Ukraine, E-mail: olenna74@gmail.com;

${ }^{2}$ Leading Research Fellow, Koretskiy Institute of State and Law of the National Academy of Sciences of Ukraine, Kyiv, Ukraine, E-mail: Pavlo.f.k@gmail.com;

${ }^{3}$ Associate Professor Lviv State University of Internal Affairs, Lviv, Ukraine,

E-mail: tetyanakurylo@ukr.net;

${ }^{4}$ Head of the Department, State GeoCadastre in Ternopil Region, Ternopil, Ukraine, E-mail: Cvigunirina247@gmail.com;

${ }^{5}$ Deputy Director, Rivne College of National University of Bioresources and Nature

Management of Ukraine, Rivne, Ukraine, E-mail: myzvk2014@gmail.com;

${ }^{6}$ Associate Professor, Kyiv National Taras Shevchenko University, Kyiv, Ukraine,

E-mail:Dligach@gmail.com;
} 


\section{Introduction}

Within the modern conditions of formation and development of the economic system of any leading country in the world, the process of land market formation plays an important role. State regulation of this area is an important factor in ensuring sustainable economic development in the country. It should be noted that the mechanism of the land market management is at a high institutional level in the leading countries of the world that is, the debugged mechanism for the sale of land has been established, land auctions have been introduced and launched, and it is possible to safely buy or sell a plot of land in accordance with national legislation through bidding. A feature of the proper functioning of the land market in the world is the presence of various forms of property rights to land. This means that the land ownership can be transitional, from state to private property and vice versa.

From this perspective, an important issue in the settlement of relations with the land is the formation of the institutional base of land turnover. Recently, there has been inefficient use of land resources, irrational and consumer's attitude to land. In the process of creating market relations, the rational use of land resources remains an important aspect. The experience of the world's leading countries can help Ukraine go faster and better through all the processes that will arise during the formation and launch of the land market. Ukraine is no exception in this situation. Despite the fact that Ukrainian lands, namely soils, are the most fertile, the country has not achieved yet the strategic goal of agrarian reform, which centers around forming highly productive landowners and transforming land resources, as well as the agricultural sector into a dominant factor of economic growth. The world's leading countries possess an effective system of state management of land resources, however not always favorable natural and geographical conditions for the development of the land market. In contrast, Ukraine has enormous agricultural potential, but does not use it to the fullest extent; in other words, Ukraine does not become a key factor in the processes of increasing the competitiveness of the domestic economy, as the country has a weak system of state management of land resources, in general, and the land market, in particular.

\section{Literature Review}

Currently, the processes related to the development of strategy and economic and legal framework for the formation of the land market remain a key area, which in turn is due to a balanced public policy, as well as the use of economic mechanisms and effective legal regulations in the land sphere. It is necessary to consider the development of economic relations "land-owner" for effective disclosure of this issue, however, first of all it is necessary to consider the definition of "land market".

Alejnikova (2012) notes that the land market should be considered as an existing set of certain legal and economic relations that may arise between individual entities 
present in the land market in the process of exchange, purchase, sale, inheritance, gift, pledge, lease.

In particular, Pankiv (2008) argues that the land market has certain elements regulating the mechanism of its functioning. Such elements include objects (facilities), entities, territorial communities, jointly owned enterprises, land market infrastructure, foreign legal entities, the legal framework of state regulation. The objects in this sense are considered as the land plots that are available in various forms of ownership (state, municipal, private). The subjects include individuals and legal entities.

According to viewpoint of Omelchak (2016) the state is directly involved in regulating the land market, while the latter uses certain mechanisms, namely legal, administrative, of organizational and economic nature, as well as it ensures the emergence of certain conditions and features.

Paschaver (2009) in his studies identifies the land market with the development of land relations, for as much as with the help of the latter it is possible to realize oneself as a landowner, that is, in order to obtain market benefits. If we consider one of the components of the land market, such as agricultural land, it should be noted that the latter can provide a certain market effect during their use, that is, during the lease, pledge, commodity production, sale. The above mentioned types of market benefits are considered as three forms of land.

In a study by Danylyshyn (1999) it has been noted that the land market should be considered as the creation of certain agreements on the sale, mortgage and lease of land. Dobryak et al. (2004) view the land market in the narrow sense of the market, namely as conducting trade operation with the land. The study of of Novakovsky et al. (2001) revealed that the concept of market should be understood as certain economic relations that arise during the process of land turnover. Kovalenko (2011), Suvorova and Ishigenov (2016) define the market as a sphere of commodity exchange. The agro-industrial complex is an incentive for the development of the land market and land lease (Shashyna et al., 2018).

The concept of the land market has a legal dimension. In our opinion, the land market as a legal category is an organizational and legal mechanism that creates the preconditions for the acquisition of land ownership or use and transfer of rights to them, as well as mediates the transfer of land and rights from one person to another; it also guarantees the inviolability of acquired land property rights. In accordance with this, the balanced structure of the organizational and legal mechanism of the land market should, in our opinion, include:

1) The institution of property right to land in its pluralistic form;

2) An effective system of state registration of property rights to land and other real estate; 
3) Legal provision of fair (market) valuation of land plots;

4) A favorable "legal field" for the market turnover of land.

At the same time, economic and legal approaches to the land market are based on the postulate that the more perfect the market is, the stronger the tendency is to pay coinstantaneously the same price for all its points.

\section{Research Methodology}

Data from Eurostat, the State Statistics Service of Ukraine for different time periods have been used to study the basic indicators of economic activity of the countries. The following methods have been used: economic and statistical to identify the basis of public management of the land market in the leading countries of the world; the method of comparative analysis to determine the average value of 1 ha of land (USD) in the world's leading countries, as well as to forecast the market value of agricultural land (arable land), USD / ha, to determine the rating of the value of agricultural land in Ukraine in 2018; the calculation and constructive method in the process of studying the scenarios of Ukrainian economic development during the introduction of the land market; the formal-legal method for the analysis of provisions of regulatory legal acts; the abstract-logical method - for analytical generalization and formulation of conclusions.

\section{Empirical Findings}

Within the modern economic conditions, the world experience of public land market management plays an important role in the formation of the strategic and tactical economic development of the state. At this stage, certain problems arise within the framework of reformation processes that take place during the emergence of land ownership relations. The basic aspect of the implementation of land reform in European Union was to form private ownership of agricultural land. With the help of land privatization and restitution, relevant land markets were created, including land lease and purchase and sale. The outlined issues need to take into account foreign experience. We propose to consider the features of public administration of the world's leading countries on the implementation and proper functioning of the land market.

The creation of specialized institutions aimed at managing state-owned lands is the main prerequisite that currently exists in the leading countries of the world during the formation and effective functioning of the agricultural land market in the member states, namely: the Slovak Land Fund has been established in Slovakia, the Agricultural Real Estate Agency has been established in Poland, the National Land Service has been established in Lithuania, the State Land Service coordinates land issues in Latvia, these functions are performed by the Land Consolidation Department in Denmark, the Land and Water Management Service has been established in the Netherlands, the institution that regulates land relations is the 
National Company "Land", established in Bulgaria. All of the above mentioned institutions aim to provide loans to producers, manage state lands, as well as consolidate land and ensure sustainable development of territories. The process of creating these organizations has helped the government avoid a number of problems during the market turnover of land (Drozdyuk, 2015; Kovalenko, 2011; Zinchuk, 2016).

Leasing is one of the main tools used to increase land use in the world's leading countries. Leased land amounts about 90\% in Bulgaria, 60\% in Estonia and Hungary. In general, leased lands occupy 53\% and also tend to increase in EU member states. About 5\% of agricultural land in EU member states is under environmental protection (Food and Agriculture Organization of the United Nations, 2020). Given the foregoing, it is worth considering the average cost of 1 hectare of land in the world's leading countries (USD) (Figure 1).

Figure 1. The average cost of 1 hectare of land in the world's leading countries (\$)

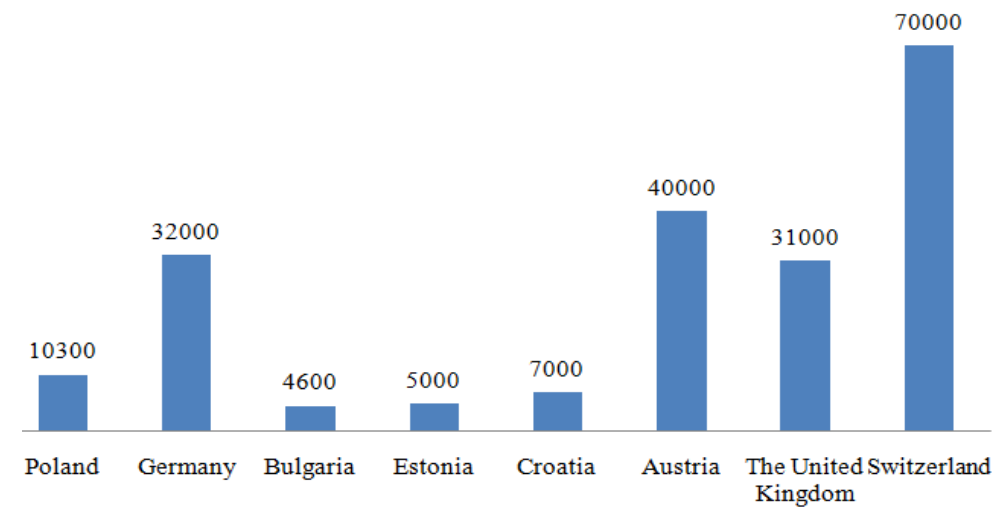

Source: World experience in land sales, 2020.

From the conducted analysis it can be seen that the highest value of 1 hectare of land is in Switzerland (70000 USD), it is followed by Austria (40000 USD) and Germany (32000 USD). This trend is due to the fact that in Switzerland 100\% of the land is privately owned, in Austria land fragmentation is prohibited, that is, only one child can inherit the land after the death of the owner, and the minimum lease term is three years. The land can be bought not only by citizens but also by foreigners in Germany, so the price is higher. The lowest average cost of land per 1 ha is observed in Bulgaria; there is no land tax, and $98 \%$ of agricultural land is privately owned.

Currently, there are 60,3 million hectares of land Ukraine, which is $6 \%$ of the entire territory of Europe. If we consider the amount of agricultural land, then this indicator is indicated at around 42,7 million hectares (70\% of the territory of Ukraine), and in relation to arable land, it occupies 32,5 million hectares $(78,4 \%$ of all agricultural land). For as much as there are about 17,4 million hectares of black earth (chernozem) in Ukraine, that is, it constitutes $8 \%$ of all world reserves. There is no free land market in Ukraine, but the relevant legislative initiatives have been 
approved, aimed at introducing the land market in the country. The land relations in Ukraine have been formed in the form of land lease for many years; they can be of two types: short-term for 7-10 years, and long-term - emphyteusis (49 years and more). If we consider how much state land is available in Ukraine, this figure is around 10,4 million hectares.

The process of reforming relations in Ukraine's land sphere, in particular in terms of land ownership, was first carried out in 1990 through the adoption of the Law "On Land Reform" No 563-XII as of December 18, 1990 (Verkhovna Rada of Ukraine, 1992b). According to this document, relations in the land sphere were to be regulated and a mechanism for equal development of various forms of land management had to be outlined only during the voluntary choice of citizens in the process of land tenure, which would guarantee protection and guarantee the rights of the latter.

In January 1992, the Law of Ukraine “On Forms of Land Ownership"No 2073-12 as of January 30, 1992 (Verkhovna Rada of Ukraine, 1992a) was adopted, according to which the following basic forms of land ownership were established: state, collective and private. The above mentioned forms of property were considered equal, although in the process of land reform collective ownership of land lost its significance. The Land Code of Ukraine, as amended on March 13, 1992, provided for the allocation of $1,3 \%$ of all agricultural land in the country for the establishment of farms (Verkhovna Rada of Ukraine, 2001).

Radical changes in the process of formation of land relations began in Ukraine not on the basis of the Land Code, but on the basis of decrees of the President of Ukraine, or more specifically, with the adoption of the Decree "On the procedure for distribution of land transferred to the collective ownership of agricultural enterprises and organizations" No 720/95 as of August 8, 1995 (Kuchma, 1995). According to this document, a special procedure was provided to carry out unbundling of land resources, as well as their transfer to ownership. In other words, the agrarian reform in Ukraine at the above mentioned stage has led to the process of land privatization, thus forming the market turnover of land resources. For the owners of land plots (shares), comfortable conditions were created by which they had the right to freely donate, sell and transfer shares. A new stage of reforming land ownership relations in Ukraine began with the adoption of the Law "On Amendments to Certain Legislative Acts of Ukraine on the Circulation of Agricultural Land" as of March 31, 2020.

According to the adopted Law, a transitional period is introduced in Ukraine from July 1, 2021 to January 1, 2024, during which only citizens of Ukraine will have the right to purchase agricultural land with an area of up to 100 hectares per person. And since January 1, 2024, the legal property right will be acquired by legal entities, the founders or ultimate beneficiaries of which are the Ukrainians. Land will not be available to those persons, who have business offshore or abroad, etc. We propose to consider the basic provisions of the Law "On Amendments to Certain Legislative 
Acts of Ukraine on the Circulation of Agricultural Land" as of March 31, 2020. It should be noted that in accordance with Article 19 of the Land Code of Ukraine, the lands in Ukraine for its basic purpose are divided into the following categories, namely: agricultural lands; forestry lands; health-improving lands; recreational lands; lands of historical and cultural significance; water fund lands; lands of nature reserves and other nature protection purposes; land for industry, transport, communications, energy, defense and other purposes; land for housing and public facilities (Verkhovna Rada of Ukraine, 1992b).

$54 \%$ of the country's territory is occupied by arable land. Ukrainian soils are famous for its fertility, however, Ukraine ranks the 11th place in the world in terms of land use and is one of the few countries in Europe where there is no market for agricultural land. Almost half of land resources are owned by the private sector (46\% of arable land), $4 \%$ of agricultural land is owned by state enterprises. At the same time, due to the absence of the land market, agricultural holdings and other large agricultural enterprises have gradually accumulated agricultural land on lease (Figure 2). Thus, the adoption of the Law "On Amendments to Certain Legislative Acts of Ukraine on the Circulation of Agricultural Land" opens new opportunities for the development of the agricultural sector of the country.

Figure 2. Forecast of the market value of agricultural land (arable land), USD / ha - limited access for foreigners $\quad$ unlimited access for foreigners

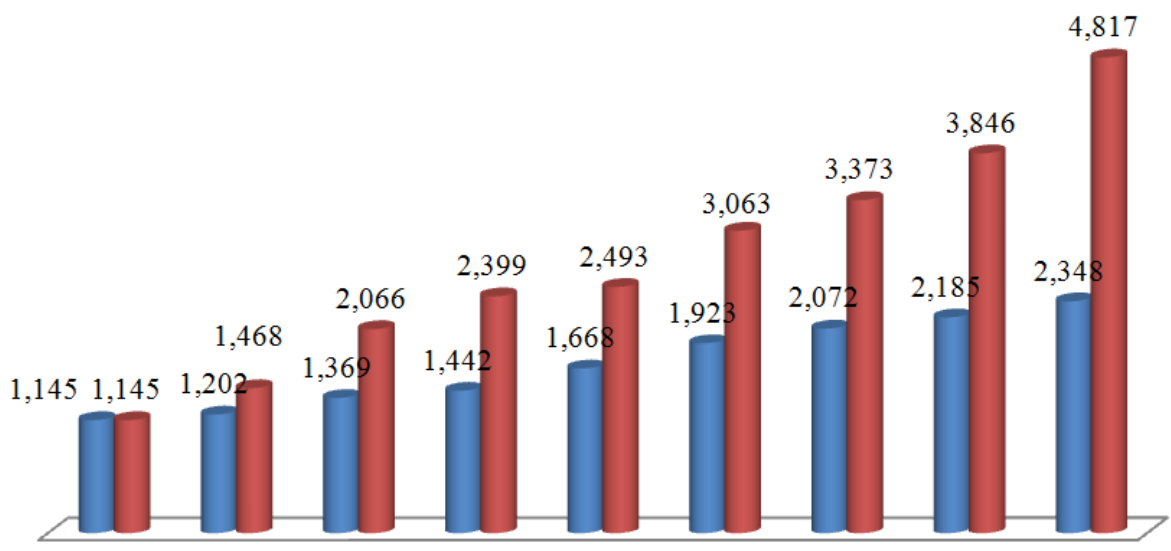

Source: Vygovskaya (2018).

However, the population of the state, which owns a third of the land $(37 \%$, most of which is arable land), is not able to sell their property at market prices. Citizens are forced to lease their shares to agricultural companies at very low prices - in Kyiv region it is 2,18 hectares for 6 thousand $\mathrm{UAH}$ per year. De facto, the land market in Ukraine is in the shadow sector; it is being formed by long-term legal trials. Thus, the lifting of the moratorium on land will ensure the liberalization of the land market, demonopolization and establishment of market value in a competitive 
environment. In addition, options for land market development should be considered.

In Poland, at the time of the opening of the land market, $75 \%$ of land was privately owned, as contrasted with other post-Soviet countries. The price of land is formed without state intervention. The tax paid by the buyer is $2-5 \%$. The market value of land in 2016 was 10,3 thousand USD for 1 ha. According to the state cadastre data, the standard cost of 1 hectare of land is 1,1 thousand USD; this figure is typical for Ukraine. In addition, it is worth considering the rating of the value of agricultural land in Ukraine in 2018 (Table 1).

Table 1. The rating of the value of agricultural land in Ukraine in 2018

\begin{tabular}{|l|l|l|}
\hline Region & Sale (USD / ha) & Rent (USD / ha) \\
\hline Cherkasy region & 1670 & 84 \\
\hline Poltava region & 1597 & 80 \\
\hline Kyiv region & 1238 & 62 \\
\hline Vinnytsia region & 1210 & 61 \\
\hline Chernivtsi region & 1143 & 57 \\
\hline Khmelnytsky region & 1128 & 56 \\
\hline Kirovograd region & 1086 & 54 \\
\hline Kharkiv region & 1045 & 52 \\
\hline Ivano-Frankivsk region & 1016 & 51 \\
\hline Ternopil region & 994 & 50 \\
\hline Dnipro region & 897 & 45 \\
\hline Lviv region & 840 & 42 \\
\hline Mykolaiv region & 831 & 42 \\
\hline Zaporizhia region & 822 & 41 \\
\hline Sumy region & 807 & 40 \\
\hline Rivne region & 801 & 40 \\
\hline Odesa region & 779 & 39 \\
\hline Kherson region & 733 & 37 \\
\hline Donetsk region & 727 & 36 \\
\hline Chernihiv region & 721 & 36 \\
\hline Zakarpattia region & 694 & 35 \\
\hline Luhansk region & 665 & 33 \\
\hline Zhytomyr region & 613 & 2 \\
\hline Volyn region & 564 & \\
\hline
\end{tabular}

Source: Vygovskaya (2018).

From the Table 1 we observe that the highest rental rates for land are lands in agricultural regions - Cherkasy, Poltava and Kyiv regions. It can be seen that the average annual rent per hectare in Cherkasy region is 84 US dollars, and in Poltava and Kyiv region - US 80 dollars and 62 US dollars, respectively. If we consider the development and proper functioning of the land market, the owners of shares in 
Cherkasy region could get 1670 US dollars per hectare, in Poltava - 1600 US dollars. In terms of Kyiv, this figure would be on the mark - 1240 US dollars, that is, these regions have expensive black soil (chernozem). The cheapest lands were as follows: the land in Volyn region - 564 US dollars, Zhytomyr region - 613 US dollars, and Luhansk region - 665 dollars. This trend can be explained by the fact that a large part of the land in Volyn is occupied by swampy area, and in Luhansk there is an armed conflict.

It is worth agreeing with Kireitseva (2016), that modern history, which is aimed at the economic development of European countries, once again confirms the hypothesis of a significant regulatory influence of the state on the formation and proper functioning of the land market. It is possible to create an effective mechanism for state regulation of the land market not only in European countries but also in Ukraine with the existing effective legislative framework and the use of certain economic levers and instruments of the state for business entities.

In addition, regarding the situation in Ukraine, we agree with researchers that the level of available land prices is underestimated; the reason for this is the presence of a monopoly on shares, and therefore the cost of rent is reduced as much as possible, that is, currently the price should be two or even five times higher. With the introduction of the land market, the price per hectare of land in Volyn region can range from 1128 US dollars up to 2820 US dollars, and as for Cherkasy region, the price per hectare is in the range from 3340 US dollars up to 8350 US dollars.

\section{Discussion and Conclusions}

Currently agricultural land is a valuable resource not only in EU member states, but also in Ukraine. In the leading countries of the world, public authorities have an opportunity to regulate the maximum size of available agricultural property on a family by means of the created corresponding mechanism. In addition, it is possible to monitor the process of compliance with the purpose of the land and to maintain its fertility. The establishment of certain rules and norms in countries that relate to obtaining permits for the purchase of agricultural land makes it possible to effectively use the land market as a kind of institution that helps achieve sustainable development of the country's economy. Herewith, it should be noted that there is a so-called "black market of land" on which the price of land is in the range of 1-2 thousand dollars per hectare and this is a reduced market price to compare with neighboring countries. For comparison, the average annual fee for shares in 2018 was 1613 UAH, that is, about 65 USD.

The basic advantages that can be achieved with the introduction and effective functioning of the land market can be as follows:

- Growth of gross domestic product (hereinafter - GDP). The experts of the World Bank take up the position that Ukraine's GDP will grow by about $2 \%$ 
over the years. Professionals are convinced that the land market will stimulate investment, increase productivity, create conditions for the use of land as the subject to mortgage; this aspect is especially important for lending to small and medium-sized farms.

- Increase in the value of land. According to the calculations of the analytical center easybusiness, the price of 1 hectare of land will reach 5 thousand dollars in about 10 years, while the total increase in gross domestic product over these years will be 64 billion US dollars.

- Additional tax revenues. The introduction of the land market will lead to additional tax revenues, because the tax will be paid at the time of purchase. This will fill the budget, the country's economy and citizens. This will be especially important for those who enjoy state support, namely beneficiaries, retirees. Ukrainian infrastructure will also be able to develop with the help of tax revenues.

- Cooperation with international creditors. In order to get the next tranche from the International Monetary Fund, a number of conditions should be met, established by this organization. Under the new loan program, which is drawn up for 3-4 years, an important condition is the introduction of the land market, which is proof of compliance with the terms of the agreement.

- Additional foreign investment. The country's economy will not be able to get about $0,5 \%$ of GDP for the expected period without foreigners, which is about 1 billion USD. That is, experts are considering the possibility of opening the land market to foreign citizens.

- Increase productivity. One of the leading sectors of Ukraine is the export of agricultural products. During 2018-2019, exports of goods amounted to 18,6 billion or $39,40 \%$ of total exports of goods from Ukraine. It should be borne in mind that these indicators are not the limit, because productivity can only increase due to additional investment.

- Therefore, Ukraine's economy will have all the trumps in hand when the moratorium on land sales is lifted, however, the market model should be taken into account, as capital gains may either increase or decrease accordingly, but it will certainly be present.

\section{References:}

Alejnikova, O.V. 2012. State regulation of the agrarian sector of the economy in the context of food supply for the population of Ukraine: theory, methodology, modern mechanisms. The monograph. T.V. Yemelyanova, Mykolayiv, Ukraine.

Danylyshyn, B.M. 1999. Natural resource potential of sustainable development of Ukraine. Nichlava, Kyiv, Ukraine.

Dobryak, D.S., Tretyak, A.M., Scallop, H.B. 2004. Theoretical principles of sustainable development of land use in agriculture. Urozhay, Kyiv, Ukraine.

Drozdyuk, T.M. 2015. Legal regulation of the land market: world experience and its use for the development of the land market in Ukraine. Economics and Law, 27, 238-244. 
Food and Agriculture Organization of the United Nations. 2020. Detailed food and agricultural trade data. Available at: http://faostat.fao.org/site/535/default.

Kireitseva, O.V. 2016. Regulation of the land market of France. International scientific magazine "Internauka", 12(22), 74-76.

Kovalenko, T.O. 2011. Legal regulation of the market of agricultural lands according to the legislation of Ukraine and Great Britain. Right, 43, 98-112.

Kuchma, L.D. 1995. Decree of the President of Ukraine on the procedure for distribution of land transferred to collective ownership of agricultural enterprises and organizations. Available at: https://zakon.rada.gov.ua/laws/show/720/95\#Text.

Novakovsky, L.Y., Tretyak, A.M., Dobryak, D.S. 2001. Land reform and land management in Ukraine, Budivelnyk, Kyiv, Ukraine.

Omelchak, K. 2016. Mechanisms of state regulation of the land market: approaches to determining the essence. Public Administration and Self-government, 2(29), 112-120.

Pankiv, Z.P. 2008. Land resources. Ivan Franko Publishing Center, Ivano-Frankivsk, Ukraine.

Paschaver, B.J. 2009. Market of the earth: world experience and national strategy. Economics of Agro-industrial Complex, 3, 47-53.

Shashyna, M.V., Zakharchenko, O.V., Darushyn, O.V., Buryk, Z.M., Shpinkovska, M.I. XXXX. The Journal of Social Sciences Research, Special Issue 5, 549-562.

Suvorova, A.V., Ishigenov, I.V. 2016. Land resource market: concepts, functions, economic essence. International Researh Journal, 3-1(45), 71-73.

Verkhovna Rada of Ukraine. 1992a. Law of Ukraine "On forms of land ownership". Available at: https://zakon.rada.gov.ua/laws/show/2073-12\#Text.

Verkhovna Rada of Ukraine. 1992b. Law of Ukraine "On land reform". https://zakon.rada.gov.ua/laws/show/563-12\#Text.

Verkhovna Rada of Ukraine. 2001. Land Code of Ukraine. Available at: https://zakon.rada.gov.ua/laws/show/2768-14\#n248.

Verkhovna Rada of Ukraine. 2020. The Law of Ukraine "On amendments to certain legislative acts of Ukraine concerning the circulation of agricultural lands". Available at: https://zakon.rada.gov.ua/laws/show/552-IX\#Text.

Vygovskaya, L. 2018. How will the Ukrainian land rise in price - the experts. Available at: https://nv.ua/amp/investitsii-v-zemlju-eksperty-o-nekomfortnuju-temu-1057604.html.

World experience in land sales: Where is the most expensive land in Europe and how the land market works there. 2020. Zik. ua. Available at:

https://zik.ua/article/dosvid_svitu_u_prodazhi_zemel_de_naidorozhchi_uhiddia_u_ye vropi_i_iak tam_pratsiuie rynok_zemli_964027.

Zinchuk, T.O. 2016. European experience in the formation of the agricultural land market. Economics of agro-industrial complex, 12, 84-92. 